\title{
Prenatal diagnosis of unilateral dacryocystocele: A rare case report
}

\section{Unilateral dakriyosistoselin prenatal tanısı: Nadir bir olgu sunumu}

\section{Cihan İnan}

\author{
Sivas Numune Hospital, Department of Perinatology, Sivas, TURKEY \\ Corresponding author: Cihan İnan, MD., Sivas Numune Hospital, Department of Perinatology, Sivas, Turkey \\ E-mail: cihan311@hotmail.com \\ Received/Accepted: November 25, 2018 / March 20, 2019 \\ Conflict of interest: There is not a conflict of interest.
}

\section{SUMMARY}

Dacryocystocele is a rare benign cystic formation seen in the lacrimal sac as a result of obstruction of the nasolacrimal duct. This lesion may coexist with additional anomalies. Most cases resolve spontaneously in the late intrauterine or early neonatal periods. They are usually unilateral and more common in female fetuses. In the literature, a very limited numbers of prenatal dacryocystocele cases have been reported. We presented a case of unilateral dacryocystocele accompanied by polyhydramnios in a male fetus which was diagnosed with obstetric ultrasonography at 29 weeks of gestation.

Keywords: Dacryocystocele, fetus, penatal diagnosis.

ÖZET

Dakrosistosel nazolakrimal kanalın obstrüksiyonu sonucu lakrimal kesede görülen oldukça nadir benign bir kistik oluşumdur. Bu lezyon ek anomalilerle birlikte bulunabilirler. Birçok vaka, geç intrauterin veya erken neonatal periyotta genellikle spontan rezolüsyona uğrar. Genellikle unilateral olurlar ve kız fetuslarda daha sik görülürler. Literatürde oldukça sınırlı sayıda prenatal dakrosistosel vakası sunulmuştur. Biz de gebeliğin 29. haftasında erkek fetusta obstretrik obstetrik ultrasonografi ile tanısı konulan, polihidramniosun eşlik ettiği, tek taraflı dakrosistosel vakasını sunduk.

Anahtar sözcükler: Dakrosistosel, fetus, prenatal tanı.

\section{INTRODUCTION}

Dacryocystocele is a rare congenital anomaly characterized by dilatation of the lacrimal sac as a result of obstruction of distal Hasner valve and proximal Rosenmuller valve in the lacrimal system. This anomaly is seen in the medial edge of the orbital cavity in the prenatal USG as an anechoic fluid-filled cystic structure ${ }^{1}$. It has been reported that dacryocystocele may coexist with additional anomalies and some syndromes. The real prevalance is not known because of more lesions resolve spontaneously ${ }^{2}$.

\section{CASE}

A 23-year-old gravidity 3 parity 2 pregnant woman who had normal screening test results was followed up in our hospital. Obstetric ultrasonograhy (USG) revealed no pathologic finding at 19 weeks of gestation. Glucose challenge test was normal. At 29 weeeks of gestation USG revealed $8.2 \times 5,1 \mathrm{~mm}$ anechoic cystic mass in the inferiomedial region of the left orbit without any blood flow in Doppler examination which was diagnosed as dacryocystocele (Figure 1,2). In addition, fetal measurements were compatible with gestational week and additionally polyhydramnios was 
detected. Although we explained that the diagnosis of genetic diseases could be made by prenatal invasive procedures such as cordocentesis, the patient did not accept any invasive procedure. The patient did not come regular follow up until delivery. A cesarean section $(\mathrm{C} / \mathrm{S})$ was performed due to previous $\mathrm{C} / \mathrm{S}$ at 39 weeks of gestation and a $3980 \mathrm{~g}, 52 \mathrm{~cm}$ male infant was delivered with Apgar scores of 9 and 10. In the neonatal examination and subsequent USG examination, dacryocystocele was not observed.

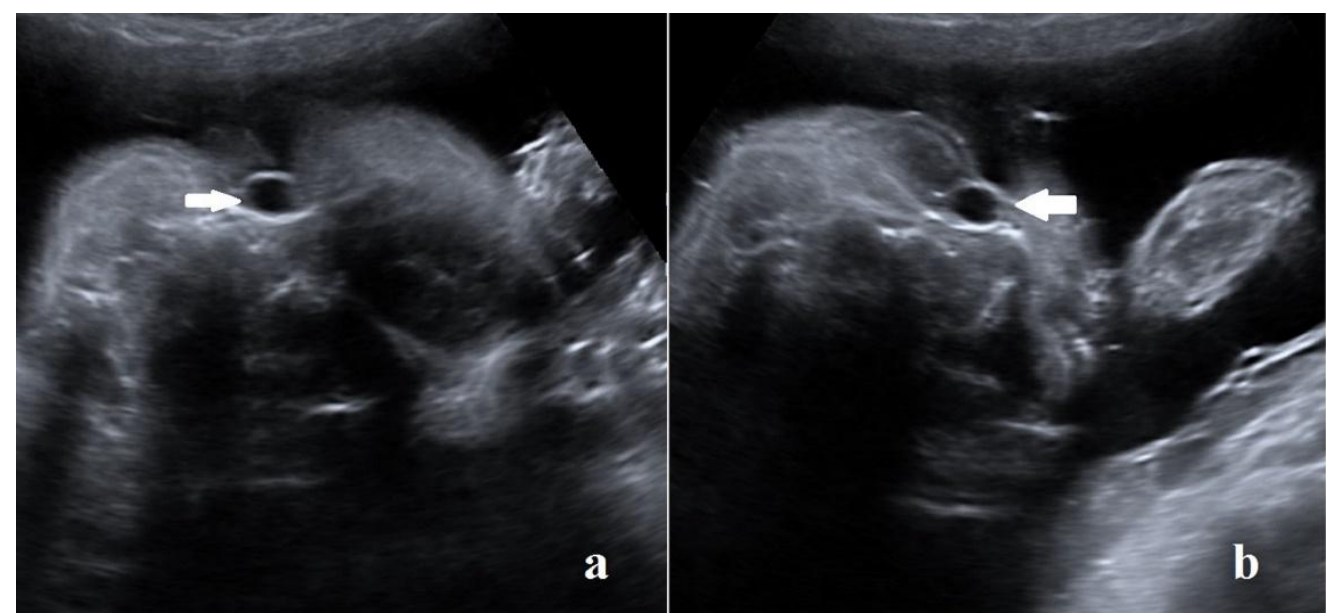

Figure 1a, b. Coronal ultrasonography images of dacryocystocele which is located in the inferomedial edge of the left orbit (white arrows).

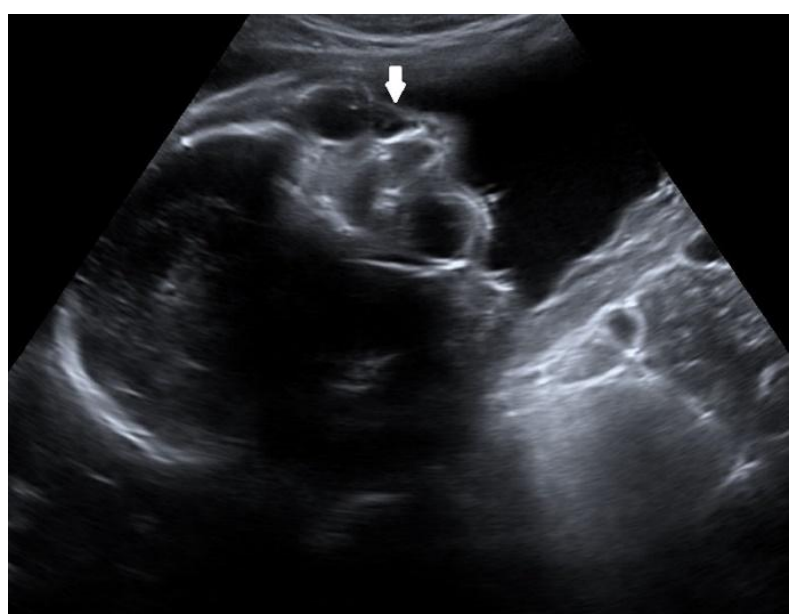

Figure 2. Axial ultrasonography image of unilateral dacryocystocele (white arrow).

\section{DISCUSSION}

Dacryocystocele is a rare anomaly, occurring in about $0.02 \%$ of newborns ${ }^{3}$. Nasolacrimal duct begins to develop from an epithelial cord at 6 weeks of gestation. The canalization of the cord starts at the end of the $12^{\text {th }}$ week from the ocular area to the nasal area. This procedure is completed in the sixth month. Failure in the canalization stage usually occurs at the Hasner valve which is located at the lower end of the nasolacrimal duct.
The lacrimal sac is filled with amniotic fluid and mucous secretions with the imperforate of Hasner valve and this process leads to distension of the sac. The cystic distension of the lacrimal sac known as dacryocystocele compresses the canal and causes mechanical or functional obstruction of the proximal Rosenmuller valve ${ }^{4}$. This fetal development explains why the early diagnosis is not possible in most cases, because this anomaly is not fully formed during detailed USG 
examination at the 18-22 weeks of gestation. Most of the cases in the literature have been diagnosed between 30 and 32 weeks ${ }^{5}$. In our case, we diagnosed the dacryocystocele at the $29^{\text {th }}$ week in accordance with the literature. We could not detect this lesion in the previous USG examinations.

Most of these anomalies are unilateral and spontaneous resolution has been reported in most prenatal cases 5 . In our case, the lesion was unilateral in accordance with the literature and it was resolved spontaneously before delivery. Although it was reported that the most lesions are found in female fetuses ${ }^{5}$, our case was male.

Prenatal diagnosis is usually made by USG and additional imaging technique such as magnetic resonance is not needed. Dacryocystocele is observed in USG examination as a hypoechoic cystic mass without vascular flow or calcification ${ }^{6}$. The dimension of the lesions is usually betweeen $8-11 \mathrm{~mm}^{7}$. In accordance with the literature, we detected approximately $8 \mathrm{~mm}$ anechoic cystic mass in the inferomedial region of the left orbit. We did not need any additional imaging technique because of its typical appearance in USG. The location of the lesion, diagnosis time, size, Doppler blood flow and echogenicity characteristics are important in terms of differential diagnosis ${ }^{7}$. Absence of blood flow in Doppler allows to distinguish dacrocystocele from other congenital anomalies such as hemangioma, glioma, anterior encephalocele or dermoid cyst ${ }^{5}$. In our case, the lesion was seen as anechoic cystic mass without any echogenicity or blood flow. These features allowed us to exclude other anomalies.

It has been reported that dacryocystocele may be accompanied with some anomalies or syndromes such as multicystic renal diseases, ectrodactylyectodermal dysplasia-clefting, Down's syndrome, craniofacial anomalies, hydrocele, Canavan disease, microphthalmia, palatoschisis and spheroidal meningocele ${ }^{6}$. In the literature it has been also reported that polyhydramnios is rarely accompanied by some cases of dacryocystocele ${ }^{8}$. In our case, in addition to dacryocystocele, polyhydramnios was also observed.

Prenatal diagnosis of dacryocystocele is important because bilateral dacryocystocele may extend intranasally and cause neonatal nasal obstruction or respiratory distress ${ }^{9}$. The presence of an enlarged bluish palpable mass covering the lacrimal sac in the newborn is usually sufficient to diagnose dacryocystocele. Sometimes skin USG examination can be used to differentiate dacrocystocele from the other lesions such as infantile hemangioma ${ }^{10}$. In our case, dacrocystocele could not be observed in physical and USG examinations in the newborn. Therefore, we thought that the lesion was resolved spontaneously during intrauterine period.

In conclusion, congenital dacryocystocele is a very rare anomaly. The presence of additional anomalies should be evaluated during prenatal diagnosis. Although in many cases the lesions resolve spontaneously, the possibility of persistence of this anomaly should be investigated with careful physical examination or imaging techniques after delivery.

\section{REFERENCES}

1. Lorena SHT, Gonçalves ED, Silva JAF. Congenital dacryocystocele: case report and treatment. Rev Bras Oftalmol 2014; 73: 243-5.

2. Kim YH, Lee YJ, Song MJ, Han BH, Lee YH, Lee KS. Dacryocystocele on prenatal ultrasonography: diagnosis and postnatal outcomes. Ultrasonography 2015; 34: 51-7.

3. Veleva N, Chernodrinska V, Mladenov O. Bilateral congenital dacryocystocele-A case report. Biomedical Research 2018; 29: 2134-5.

4. Bachelard-Serra $M$, Chau $C$, Farinetti A, Roman S, Triglia JM, Nicollas R. Prenatal diagnosis of congenital dacryocystocele. Int $\mathrm{J}$ Pediatr Otorhinolaryngol 2013; 77: 847-9.

5. Li SL, Luo GY, Tian XX, et al. Prenatal diagnosis and perinatal outcome of congenital dacryocystocele: a large case series. Prenat Diagn 2015; 35: 103-7.

6. Bonilla-Musoles F, Jimenez LC, Castillo JC. Congenital dacryocystocele: a rare and benign nasolacrimal duct cyst condition. Donald School J Ultrasound Obstet Gynecol 2012; 6: 233-6.

7. Sakin O, Kars K, Karşıdağ AYK, Demir C, Büyükbayrak EE. Prenatal diagnosis of dacryocystocele. CausaPedia 2015; 4: 1117-21.

8. Adam SH, Meulles L, Jain V. Antenatal diagnosis of dacryocystocele. J Obstet Gynaecol Can 2013; 35: 591.

9. Bingöl B, Başgül A, Güdücü N, Işci H, Dünder I. Prenatal early diagnosis of dacryocystocele, a case report and review of literature. J Turk Ger Gynecol Assoc 2011; 12: 259-62.

10. Vázquez-Osorio I, Hernández-Martín A. Usefulness of Ultrasonography in the Diagnosis of Neonatal Dacryocystocele. Pediatr Dermatol 2017; 34: 209-10. 